\title{
REVIEW
}

\section{Recent advances in the research on biological roles of dietary polyamines in man}

\section{Pavel Kalač}

Department of Applied Chemistry, Faculty of Agriculture, University of South Bohemia, České Budějovice, Czech Republic

Received $15^{\text {th }}$ May 2009.

Revised $19^{\text {th }}$ May 2009.

Published online $10^{\text {th }}$ June 2009.

\begin{abstract}
Summary
The ubiquitous polyamines putrescine, spermidine and spermine fulfil an array of physiological roles in man. In particular, their participation in cell growth and proliferation has been of great interest in relation to their roles in tumour growth and in wound healing. Both endogenous and dietary polyamines take part in such processes. The deprivation of exogenous polyamines emerges as a promising strategy in tumour therapy. Thus, reliable information on their content in foods is needed for dieticians. This review continues our previous comprehensive review on the topic, summarising data on the polyamine content in foods published from 2005 to April 2009. Some new data has appeared. Bovine, porcine and chicken liver, kidney, spleen and heart all have a high content of spermine; bovine liver also of spermidine. Losses of spermidine and spermine up to one half of their original levels occur during both cold and frozen storage and during various thermal treatments. Cultivated mushrooms were reported to contain very high levels of spermidine. Recent results have proved that polyamine content varies widely within a food item, and this complicates the application of available data for the controlled nutrition of patients.
\end{abstract}

Key words: polyamines; food; putrescine; spermidine; spermine

\section{INTRODUCTION}

The biologically active polyamines putrescine [PUT, butane-1,4-diamine], spermidine [SPD, $N$-(3-aminopropyl)-butane-1,4-diamine] and spermine [SPM, $N, N^{\prime}$-bis(3-aminopropyl)-butane-1,4-diamine] (Fig. 1) have traditionally been classified within the group of biogenic amines. However, they started to be

Pavel Kalač, Department of Applied Chemistry, Faculty of Agriculture, University of South Bohemia, 37005 České Budějovice, Czech Republic

kalac@zf.jcu.cz

+420389032657

$+420385310405$ considered separately during the 1990 s, because of their roles in the growth and function of normal cells and due to their mode of formation (Kusano et al. 2008). Putrescine, though structurally a diamine, is also classified as a polyamine due to its role as the precursor of both physiological ("true") polyamines (PUT $\rightarrow$ SPD $\rightarrow$ SPM). Among their biological roles, participation in cell growth and proliferation has been of primary interest, as polyamines, both formed endogenously and taken from diet, can be involved in tumour development. The physiological research into polyamines has thus been very extensive and dynamic. The main roles of polyamines in health and disease have been reviewed (Gugliucci 2004, Moinard et al. 2005, Larqué et al. 2007), and, moreover, various aspects of the physiological roles of polyamine were covered in a recent book (Dandrifosse 2009). 

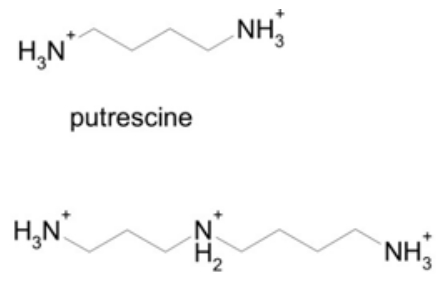

spermidine

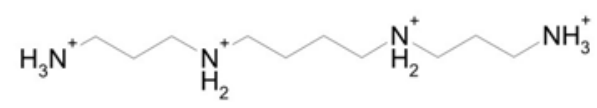

spermine

Fig. 1. Formulae of polyamines in their cationic forms.

The polyamine body pool is maintained by three primary sources: (i) endogenous (de novo) biosynthesis, (ii) production by intestinal microorganisms, and (iii) dietary intake. Diet provides a larger daily quantity of polyamines than does endogenous biosynthesis (Bardócz 1995). Information on the content of polyamines in foods and beverages would thus be of great interest for assessing their dietary intake (Zoumas-Morse et al. 2007).

The aim of the article is to review briefly current knowledge on the biological implications for human health of dietary polyamines and to collect recent data on polyamine content in foods, available notably during the five-year period since a review on the topic was last published (Kalač and Krausová 2005).

\section{POLYAMINES FORMATION AND CATABOLISM}

Polyamines are ubiquitous cell constituents of all eukaryotic organisms. Mammalian biosynthetic pathways are given in Figure 2. The biosyntheses from arginine and methionine are very effectively regulated by two key enzymes, ornithine decarboxylase and $S$-adenosylmethionine decarboxylase, respectively.

In healthy cells, polyamine levels are intricately controlled by the biosynthetic and catabolic enzymes. Catabolism of SPD and SPM proceeds as oxidase-catalysed oxidative deaminations and consecutive transformation of the primary reaction products (Seiler 2004, Wang and Casero 2006). Some of the final products, namely hydrogen peroxide, acrolein, 3-aminopropanal, 3-acetamidopropanal and 4-aminobutanal, may play pivotal roles in the development and progression of some grave neurodegenerative diseases (Wood et al. 2007).

\section{BIOLOGICAL ROLES IN MAN}

PUT, SPD and SPM under physiological conditions are flexible polycations exhibiting 2, 3 or 4 positive charges, respectively (see Fig. 1). This determines them as essential factors for the growth, maintenance and function of normal cells. Multiple abnormalities in the control of polyamine metabolism might be implicated in several pathological processes (Moinard et al. 2005).

\section{Participation in tumour growth}

Due to the above mentioned participation in cell growth and proliferation, polyamines accumulate in cancerous tissues and their content is elevated in the body fluids of cancer patients. Drugs which inhibit the biosynthesis of polyamines can prevent cancer and may also be used for therapeutic purposes. The chemopreventive or anti-neoplastic agents investigated mainly include inhibitors of ornithin decarboxylase and polyamine structural analogues and derivatives (Bachrach 2004, Casero and Marton 2007).

The second orientation is on polyamine catabolism and catabolic products. Among them, acrolein seems to be a key compound which is both carcinogenic and cytotoxic. The balance of amine oxidases and antioxidant enzymes appears to be a crucial point for cancer inhibition or progression. A long-lasting imbalance of these enzymes seems to be carcinogenic, while, for a short time, amine oxidases are cytotoxic for cancer cells (Toninello et al. 2006). The interest of researchers has recently been focused on spermine oxidase, the only catabolic enzyme able to oxidise spermine specifically (Amendola et al. 2009).

Nevertheless, tumour cells have the ability to uptake extracellular polyamines, both dietary and produced by intestinal bacteria, and to reduce the effects of the therapeutic agents referred to above. Another approach thus started in the 1990's deprivation of exogenous polyamines. Most of the reported results of this therapeutic strategy deal with laboratory experiments. However, preliminary clinical trials with prostate cancer patients show that the 


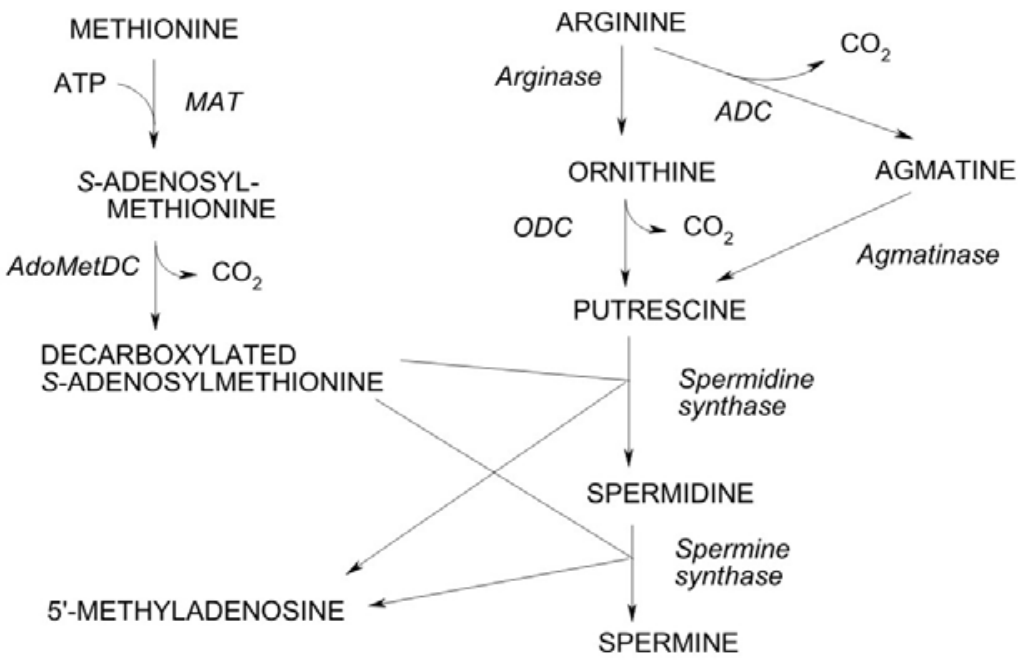

Fig. 2. Mammalian polyamine biosynthetic pathway (adapted from Hillary and Pegg 2003). The pathway via agmatin, existing in plants, was proposed also for mammals. The enzymes are written in italic ( $A D C$ - arginine decarboxylase; AdoMetDC $-S$ adenosylmethionine decarboxylase; $M A T$ - methionine adenosyltransferase; $O D C$ - ornithine decarboxylase).

reduction of dietary polyamine intake and partial intestinal decontamination is a well-observed and tolerated regimen, which seems to be beneficial for patient quality of life and pain control (Cipolla et al. 2007). Polyamines were identified as participating in almost all stages of colorectal tumorigenesis. Some components of diet, namely flavonoids, polyphenols and probiotics, can reduce the rate of hyperproliferation due to the effects on polyamine metabolism (Linsalata and Russo 2008).

\section{Effects on intestinal tract}

Dietary polyamines play a significant role in the growth and development of the digestive system of neonates and are necessary for the maintenance of the normal growth and general properties of the adult digestive tract (for a review see Deloyer et al. 2001).

The gastrointestinal tract can represent a significant source of polyamines originating from intestinal bacteria, sloughed cells and pancreatic bile and intestinal secretions. Considerable polyamine levels were observed in the lumen of human gut during the fasting state, which suggests endogenous secretion. A significantly higher content was determined in the jejunum than in the ileum, which suggests proximal absorption.

Initial studies deal with the ability of various microbiota species of human intestine to produce polyamines (Matsumoto and Benno 2007) and with the differences of such ability in healthy adults and patients with intractable adult-type atopic dermatitis (Matsumoto et al. 2007).

Studying inflammatory bowel disease, Weiss et al. (2004) observed an increased SPD content in colonic epithelial cells from the most severely inflamed mucosal areas, and enhanced SPD and SPM levels in acute colitis, whereas in chronic inflammation, SPM concentrations in colonic epithelial cells were decreased.

\section{Antioxidant effects}

Among other biological effects of polyamines, their antioxidant ability seems to participate in the reduction of cell membranes and DNA damage. Polyamines at physiological concentrations are potent scavangers of hydroxyl radicals and SPD and SPM can also quench both singlet oxygen at higher concentrations (Das and Misra 2004) and hydrogen peroxide (Rider et al. 2007).

The antioxidant and/or lysosomal stabilisation properties of polyamines apparently cause anti-inflammatory activity in acute and chronic inflammation (Lagishetty and Naik 2008).

Toxicity, risk of nitrosamines formation

The acute oral toxicity of individual polyamines, determined in Wistar rats, was observed to be 2000, 600 and $600 \mathrm{mg} \mathrm{kg}^{-1}$ body weight for PUT, SPD and SPM, respectively. The no-observed-adverse-effect level (NOAEL) was 180, 83 and $19 \mathrm{mg} \mathrm{kg}^{-1}$ body 
weight for PUT, SPD and SPM, respectively (Til et al. 1997). Such extreme intakes of dietary amines cannot be imagined.

Spermidine or putrescine can react under acidic conditions with nitrous acid forming $\mathrm{N}$-nitrosopyrrolidine. Nevertheless, information on this reaction in foods has been very scarce and nirosamine formation from polyamines does not seem to pose a health risk.

\section{POLYAMINES IN FOODS}

Besides the mostly adverse biological effects given above, dietary polyamines may be required in wound healing. Thus, reliable information on their content in foods has been needed for dieticians. Data available up to 2004 have been reviewed (Kalač and Krausová 2005) and only the more recently reported results will be discussed.

Polyamines are present in cells in free and conjugated forms. In plant tissues, polyamines are bound covalently to a partner molecule such as phenolic compounds or membrane phospholipids, and can be released by hydrolysis with a strong acid. Some binding, preferably with proteins, can be supposed in animal tissues; however, proven information is lacking. Most of the accessible data do not differentiate free and conjugated polyamines in foods.

Spermidine and spermine in foods originate from raw plant and animal tissues; a limited proportion may be formed by microbiota already present. Commonly, increased SPD and SPM levels may be supposed in young and quickly growing organisms and mainly in metabolically highly active tissues and organs (Nishimura et al. 2006). Higher PUT levels in fresh food raw materials are rare, but exist in some items of plant origin. Putrescine contents increase, even considerably, due to the high activity of several groups of bacteria, mainly Enterobacteriaceae and Clostridium spp. under inappropriate storage and handling conditions.

Unfortunately, daily cellular requirements for the polyamines have not yet been determined. The role of dietary polyamine intake increases in elderly people along with a limited ability to biosynthesise them (Larqué et al. 2007).

\section{Intake of dietary polyamines}

Mean daily intake of 18.7, 12.6 and $11.0 \mathrm{mg}$ of PUT, SPD and SPM, respectively, was reported for the United Kingdom, Italy, Spain, Finland, Sweden and the Netherlands (Ralph et al. 1999). The values adopted for Japan were 9.9, 12.0 and $7.9 \mathrm{mg}$ (Nishibori et al. 2007) and for a USA convenient sample diet 14.0, 7.9 and $7.2 \mathrm{mg}$ were selected (Zoumas-Morse et al. 2007).

Comparing dietary polyamine intake in Europe (France, United Kingdom, Sweden, Italy, Germany and the Netherlands), USA and Japan, Weiger at al. (2005) reported high polyamine intake from similar European and USA diets (Western style nutrition), while the Japanese diet represented a significantly lower source. Putrescine was the major polyamine in all three diets, but at a lower level in Japan. Intake of SPM was comparable in all diets, and that of SPM was lowest again in Japan.

The cited papers state dairy products due to high PUT level as the main source of polyamine intake in Europe and USA, while in Japan, where there is a low consumption of cheese it is vegetables. Vegetables are the main source of SPD; meat and meat products the main source of SPM.

\section{Recent original papers with overall data}

Several papers dealing with polyamine content in a wide range of food items have been published in recent years (Nishimura et al. 2006, Cipolla et al. 2007, Larqué et al. 2007, Nishibori et al. 2007). Some of the published data confirmed previously available results, and some brought new information which will be discussed in the following sections.

However, the published data both in these and previously published papers mostly give the results of the analyses of a limited number of samples per food item. It should be noted here that polyamine contents vary widely within an item. Moreover, most of the data are given for fresh foods or raw materials, while information on the effects of various storage conditions and industrial and culinary treatments has been very limited. The possibility of setting up credible "tabular values" is thus presently very limited.

\section{Polyamines in foods of animal origin}

Spermine contents are commonly higher in foods of animal origin then those of SPD, which is an inverse relation to that observed in materials of plant origin.

Literature data on polyamine content in raw and processed beef, pork and meat products available up to 2005 have been reviewed (Kalač 2006). Recent results on fresh meat and pluck of warm-blooded animals are given in Table 1. Putrescine contents were mostly not detectable with bovine liver being an exception. Most of the pork and beef samples had SPD content below detection limits, while levels in all chicken meat samples were quantifiable. The content of both SPD and SPM in pluck or chicken giblets 
analysed are considerably higher than in meat, and are among the highest levels observed in foods. Surprisingly, bovine liver has a higher content of SPD than of SPM; in porcine spleen the levels of both of the polyamines are comparable.

Data on polyamine changes in beef, pork, chicken meat and porcine liver and kidney under various storage conditions and thermal processing have became available during the period since 2006 .

Under cold conditions, three ways of storage were tested (i) aerobic packaging in a foil, simulating household practice, (ii) vacuum packaging and (iii) packaging under a modified atmosphere up to 9, 21 and 21 days, respectively. Low SPM losses were observed in beef loin (Kozová et al. 2009b) and pork loin (Krausová et al. 2008), while losses of up to $40 \%$ (in all referred values given as \% from the initial content in fresh packaged material) were noted in chicken meat (Kozová et al. 2009a). Losses of up to $40 \%$ were reported for porcine liver (Krausová et al. 2007) and kidney (Kozová et al. 2008).

Results on polyamine changes during several-month storage at $-18{ }^{\circ} \mathrm{C}$ are not uniform. Spermine content in beef loin slightly increased during the initial two months of storage and then decreased by about $30 \%$ after a six-month storage period (Kozová et al. 2009b), while in pork loin, changes were insignificant (Krausová et al. 2008). Contradictory changes were reported for chicken meat. Kozová et al. (2009a) observed an increase of both SPD and SPM contents after six months of frozen-storage, whereas Moreira et al. (2008) determined heavy shrinkage of 70 and $80 \%$ for SPD and SPM, respectively, after a three-month storage. Krausová et al. (2007) reported losses of about $30 \%$ in porcine liver frozen for six months.

The effects of various culinary thermal treatments on changes in polyamine contents were reported for beef loin (Kozová et al. 2009b), pork loin (Paulsen et al. 2006, Paulsen and Bauer 2006, Krausová et al. 2008), chicken breast (Kozová et al. 2009a), porcine liver (Krausová et al. 2007) and porcine kidney (Kozová et al. 2008). Overall, losses of both SPD and SPM were usually about $40 \%$. Shrinkage at lower temperature processing, such as boiling, stewing or grilling seems to be lower than that caused by frying or roasting. No polyamines were detected in broth and grease.

Unfortunately, no data are recently available on the nature of polyamine losses during meat - and indeed all food storage and processing. The knowledge available on polyamine catabolism in living cells cannot be applied to processes in food materials.

Following the previous review (Kalač 2006), research results on changes of polyamines during processing and storage of various meat products were miscellaneous. There were some reports mostly of an increase of PUT content, but of an increase or decrease in or stability of the content of SPD and SPM.

Only a few original papers have been published on the topic during the period since 2006, and these deal with traditional Spanish and Turkish meat products. The contents of SPD and SPM in freshly prepared products prior to fermentation and drying fit well with the data in Table 1 for beef and pork. Putrescine content usually increased to levels of tens or hundreds $\mathrm{mg} / \mathrm{kg}$ in final products. In several types of dry-fermented sausages, an increase of SPD and SPM during processing was reported. However, the increase could be due to water losses, as the contents of both polyamines were not corrected to original dry matter content (Ruiz-Capillas et al. 2007, Genccelep et al. 2007, Lorenzo et al. 2008, Kurt and Zorba 2009).

In lacón, a Spanish product similar to dry-cured ham, SPD content remained stable during 84 days of ripening in both experimental variants, either produced with salt only or with additives (glucose, nitrite, nitrate, ascorbate and citrate). Spermine content decreased during the period by 42 and $13 \%$ in the variant without and with the additives, respectively (Lorenzo et al. 2007).

Polyamine content in the flesh of both sea and freshwater fish is very low after capture. Putrescine content can increase after inappropriate storage and handling conditions.

As reviewed by Michaelidou (2008), the content of all polyamines in bovine, caprine, ovine and also in human milks are very low. As in other proteinaceous materials, putrescine content can increase considerably by bacterial activity not only due to inappropriate storage conditions, but also by the activity of some lactic acid bacteria during the making of ripening cheeses (for a review see Kalač and Glória 2009).

As in fish and milk, polyamines occur in eggs at very low levels and this item remains at the edge of interest.

\section{Polyamines in foods of plant origin}

As mentioned above, vegetables and fruits are the main sources of PUT intake, and vegetables that of SPD intake. Spermine contents are usually low in foods of plant origin.

Some foods have a considerably high mean PUT level, usually above $40 \mathrm{~m} / \mathrm{kg}$, namely: oranges, orange juice (recently Vieira et al. 2007 with mean content $33.6 \mathrm{mg} / \mathrm{l})$, mandarins, grapefruit juice, and 
Table 1. Content of polyamines ( $\mathbf{m g} / \mathbf{k g})$ in fresh meat and pluck/giblets. Putrescine contents were mostly below limits of quantification of the analytical methods used. Spermine contents were detectable only in a limited proportion of samples.

\begin{tabular}{|c|c|c|c|c|c|c|c|c|c|c|c|c|}
\hline \multirow[b]{2}{*}{ Product } & \multirow[b]{2}{*}{ Country } & \multirow[b]{2}{*}{$\mathrm{n}$} & \multicolumn{3}{|c|}{ Putrescine } & \multicolumn{3}{|c|}{ Spermidine } & \multicolumn{3}{|c|}{ Spermine } & \multirow[t]{2}{*}{ Reference } \\
\hline & & & $\mathrm{x}$ & $\mathrm{s}_{\mathrm{x}}$ & $\mathrm{r}$ & $\mathrm{x}$ & $\mathrm{s}_{\mathrm{x}}$ & $\mathrm{r}$ & $\mathrm{x}$ & $\mathrm{s}_{\mathrm{x}}$ & $\mathrm{r}$ & \\
\hline \multicolumn{13}{|l|}{ Beef } \\
\hline Sirloin & Czech Rep. & 63 & - & - & - & - & - & $1.0-2.9$ & 21.7 & 5.8 & $2.1-31.5$ & Krausová et al. 2006a \\
\hline Rump & Czech Rep. & 57 & - & - & - & - & - & $1.2-2.4$ & 22.0 & 5.6 & $10.0-75.0$ & Krausová et al. 2006a \\
\hline \multicolumn{13}{|l|}{ Pork } \\
\hline Loin - barrows & Czech Rep. & 15 & - & - & - & - & - & $1.1-6.6$ & 26.1 & 7.0 & $7.7-35.1$ & Krausová et al. 2006a \\
\hline Loin - gilts & Czech Rep. & 12 & - & - & - & - & - & - & 22.3 & 10.6 & $4.3-41.4$ & Krausová et at. 2006a \\
\hline Loin & Austria & 72 & - & - & - & 3.0 & 1.1 & - & 20.7 & 5.9 & - & Paulsen and Bauer 2007 \\
\hline Leg - barrows & Czech Rep. & 15 & - & - & - & - & - & $1.3-5.3$ & 28.4 & 8.5 & $8.2-42.2$ & Krausová et al. 2006a \\
\hline Let - gilts & Czech Rep. & 12 & - & - & - & - & - & $1.3-5.6$ & 18.3 & 9.3 & $3.0-29.5$ & Krausová et al. 2006a \\
\hline \multicolumn{13}{|l|}{ Chicken } \\
\hline Breast & Brazil & 30 & 1.0 & - & - & 27.4 & 1.9 & - & 38.7 & 2.4 & - & Moreira et al. 2008 \\
\hline Breast & Czech Rep. & 20 & - & - & - & 4.8 & 1.7 & - & 36.8 & 5.9 & - & Kozová et al. 2009a \\
\hline Thigh & Czech Rep. & 20 & - & - & - & 10.2 & 2.2 & - & 38.0 & 3.7 & - & Kozová et al. 2009a \\
\hline Skin & Czech Rep. & 10 & - & - & - & 11.4 & 1.7 & - & 24.3 & 3.8 & - & Kozová et al. 2009a \\
\hline \multicolumn{13}{|l|}{ Pluck/giblets } \\
\hline Young bull liver & Czech Rep. & 58 & 23.8 & 41.7 & $2.2-259$ & 122 & 82.0 & $9.9-390$ & 43.1 & 26.5 & $11.5-128$ & Krausová et al. 2006b \\
\hline Cow liver & Czech Rep. & 19 & 25.4 & 17.8 & $4.1-63.0$ & 161 & 62.5 & $70.7-331$ & 34.7 & 19.6 & $13.4-82.2$ & Krausová et al. 2006b \\
\hline Barrow liver & Czech Rep. & 19 & - & - & - & 32.1 & 11.6 & $15.7-56.6$ & 115 & 49.4 & $65.4-207$ & Krausová et al. 2006b \\
\hline Gilt liver & Czech Rep. & 17 & - & - & - & 31.8 & 11.5 & $14.3-56.5$ & 114 & 40.8 & $53.4-219$ & Krausová et al. 2006b \\
\hline
\end{tabular}




\begin{tabular}{|c|c|c|c|c|c|c|c|c|c|c|c|c|}
\hline Lamb liver & Czech Rep. & 9 & - & - & - & 22.2 & 16.1 & $7.7-57.0$ & 113 & 30.4 & $63.2-165$ & Krausová et al. 2006b \\
\hline Roe deer liver & Austria & 39 & 2.4 & - & ND-49.7 & 8.5 & 3.25 & $3.9-18.8$ & 94.6 & 23.3 & $49.9-147$ & Paulsen et al. 2008 \\
\hline Brown hare liver & Austria & 20 & 2.2 & - & ND-4.4 & 37.2 & 12.4 & $22.2-63.4$ & 111 & 24.9 & $60.3-169$ & Paulsen et al. 2008 \\
\hline \multirow[t]{2}{*}{ Chicken liver } & Czech Rep. & 38 & - & - & - & 56.9 & 15.1 & $17.0-84.5$ & 120 & 43.0 & $35.2-211$ & Krausová et al. 2006b \\
\hline & Czech Rep. & 20 & - & - & - & 48.7 & 8.8 & - & 133 & 18.0 & - & Kozová et al. 2009a \\
\hline Porcine kidney & Czech Rep. & 40 & - & - & - & 9.4 & 3.4 & $5.7-17.7$ & 53.1 & 14.0 & $32.8-88.5$ & Kozová et al. 2008 \\
\hline Roe deer kidney & Austria & 39 & - & - & - & 10.7 & 5.3 & $4.2-38.6$ & 79.9 & 15.0 & $27.9-117$ & Paulsen et al. 2008 \\
\hline Brown hare kidney & Austria & 20 & - & - & - & 24.4 & 4.1 & $15.1-32.0$ & 82.8 & 13.8 & $57.7-114$ & Paulsen et al. 2008 \\
\hline Porcine spleen & Czech Rep. & 10 & - & - & - & 36.7 & 5.7 & $30.2-51.9$ & 34.0 & 7.6 & $25.3-53.6$ & Kozová et al. 2008 \\
\hline Roe deer spleen & Austria & 39 & - & - & - & 42.9 & 11.8 & $4.9-80.8$ & 102 & 19.8 & $68.4-137$ & Paulsen et al. 2008 \\
\hline Brown hare spleen & Austria & 20 & - & - & - & 52.0 & 13.9 & $23,5-75.5$ & 91.1 & 23.5 & $50.6-139$ & Paulsen et al. 2008 \\
\hline Chicken heart & Czech Rep. & 20 & - & - & - & 12.1 & 3.3 & - & 82.7 & 10.4 & - & Kozová et al. 2009a \\
\hline
\end{tabular}

$\mathrm{n}$ - number of samples; $\mathrm{x}-$ mean; $\mathrm{s}_{\mathrm{x}}-$ standard deviation; $\mathrm{r}$ - range; $\mathrm{ND}$ - below detection limit 
sauerkraut, ketchup, frozen peas and fermented soy products (e.g. tofu and sauce, Righetti et al. 2008) among the processed products. Legumes, mainly soybean, pear, cauliflower and broccoli belong to the group of food items with SPD contents usually above $30 \mathrm{mg} / \mathrm{kg}$. The same foods, especially legumes, have also the highest SPM levels (for detailed reviewed data see Kalač and Krausová 2005).

A decrease of SPD content in vegetables was observed during a three-week storage at $6-8{ }^{\circ} \mathrm{C}$ (Moret et al. 2005). In widely consumed spinach with initial SPD and SPM contents $28.9 \pm 9.6$ and $3.6 \pm$ $1.8 \mathrm{mg} / \mathrm{kg}$, respectively, the decrease during 15-day storage at $6{ }^{\circ} \mathrm{C}$ was considerable in SPD and less extensive in SPM (Lavizzari et al. 2007).

An increasing interest in the consumption of germinated seeds induced research into polyamine contents in sprouts. Glória et al. (2005) reported an increase of all polyamines in soy sprouts, with SPD and SPM accumulated in the cotyledon, and PUT in the radicle and hypocotyl. Similarly, the increase of both SPD and SPM during sprouting was observed in broccoli, radish (Martínez-Villaluenga et al. 2008) and alfalfa, but not in fenugreek (Frías et al. 2007).

\section{Cultivated mushrooms}

Very high SPD contents, often in the range of $100-200 \mathrm{mg} / \mathrm{kg}$, were reported for common species of mushrooms cultivated in Japan (Nishimura et al. 2006, Nishibori et al. 2007). Spermine levels were considerably lower, usually below the limit of quantification, and PUT contents were mostly below $10 \mathrm{mg} / \mathrm{kg}$. Thus, mushrooms currently seem to be the food item with the highest SPD level.

\section{ACKNOWLEDGEMENT}

The review was prepared within the project MSM 6007665806 of the Czech Ministry of Education, Youth and Sport. The author acknowledges financial support of the project.

\section{REFERENCES}

Amendola R, Cervelli M, Fratini E, Polticelli F, Sallustio DE, Mariottini P: Spermine metabolism and anticancer therapy. Curr Cancer Drug Targ 9:118-130, 2009.

Bachrach U: Polyamines and cancer: Minireview article. Amino Acids 26:307-309, 2004.

Bardócz S: Polyamines in food and their consequences for food quality and human health. Trends Food Sci Technol 6:341-346, 1995.

Casero RA, Marton LJ: Targeting polyamine metabolism and function in cancer and other hyperproliferative diseases. Nature Rev Drug Discov 6:373-390, 2007.

Cipolla BG, Havouis R, Moulinoux JP: Polyamine contents in current foods: a basis for polyamine reduced diet and a study of its long term observance and tolerance in prostate carcinoma patients. Amino Acids 33:203-212, 2007.

Dandrifosse G: Biological Aspects of Biogenic Amines, Polyamines and Conjugates, Transworld Research Network, Trivandrum, India 2009, 438 pp.

Das KC, Misra HP: Hydroxyl radical scavenging and singlet oxygen quenching properties of polyamines. Mol Cell Biochem 262:127-133, 2004.

Deloyer P, Peulen O, Dandrifosse G.: Dietary polyamines and non-neoplastic growth and disease. Eur J Gastroenterol Hepatol 13:1027-1032, 2001.

Frías J, Martínez-Villaluenga C, Gulewicz $\mathrm{P}$, Perez-Romero A, Pilarski R, Gulewicz K, Vidal-Valverde C: Biogenic amines and HL60 cytotoxicity of alfalfa and fenugreek sprouts. Food Chem 105:959-967, 2007.

Genccelep H, Kaban G, Kaya M: Effects of starter cultures and nitrite levels on formation of biogenic amines in sucuk. Meat Sci 77:424-430, 2007.

Glória MBA, Tavares-Neto J, Labanca RA: Influence of cultivar and germination on bioactive amines in soybeans (Glycine max L. Merill). J Agric Food Chem 53:7480-7485, 2005.

Gugliucci A: Polyamines as clinical laboratory tools. Clin Chim Acta 344:23-35, 2004.

Hillary RA, Pegg AE: Decarboxylases involved in polyamine biosynthesis and their inactivation by nitric oxide. Biochim Biophys Acta 1647:161-166, 2003.

Kalač P: Biologically active polyamines in beef, pork and meat products: A review. Meat Sci 77:1-11, 2006.

Kalač P, Glória MBA: Biogenic amines in cheeses, wines, beers and sauerkraut. In Dandrifosse $G$ (ed.): Biological Aspects of Biogenic Amines, Polyamines and Conjugates, Transworld Research Network, Trivandrum, India 2009, pp. 267-310.

Kalač P, Krausová P: A review of dietary polyamines: Formation, implications for growth and health and occurrence in foods. Food Chem 90:219-230, 2005.

Kozová M, Kalač P, Pelikánová T: Biologically 
active polyamines in pig kidneys and spleen: Content after slaughter and changes during cold storage and cooking. Meat Sci 79:326-331, 2008.

Kozová M, Kalač P, Pelikánová T: Contents of biologically active polyamines in chicken meat, liver, heart and skin after slaughter and their changes during meat storage and cooking. Food Chem 116:419-425, 2009a.

Kozová M, Kalač P, Pelikánová T: Changes in the content of biologically active polyamines during beef loin storage and cooking. Meat Sci 81:607-611, 2009b.

Krausová P, Kalač $\mathrm{P}$, Kř́ižek M, Pelikánová T: Content of polyamines in beef and pork after animal slaughtering. Eur Food Res Technol 223:321-324, 2006a.

Krausová $\mathrm{P}$, Kalač $\mathrm{P}$, Kř́̌žek $\mathrm{M}$, Pelikánová T: Content of biologically active polyamines in livers of cattle, pigs and chickens after animal slaughter. Meat Sci 73:640-644, 2006b.

Krausová $\mathrm{P}$, Kalač $\mathrm{P}$, Křížek M, Pelikánová T: Changes in the content of biologically active polyamines during storage and cooking of pig liver. Meat Sci 77:269-274, 2007.

Krausová $\mathrm{P}$, Kalač $\mathrm{P}$, Kř́žžek M, Pelikánová T: Changes in the content of biologically active polyamines during pork loin storage and culinary treatments. Eur Food Res Technol 226:1007-1012, 2008.

Kurt S, Zorba Ö: The effects of ripening period, nitrite level and heat treatment on biogenic amine formation of "sucuk" - a Turkish dry fermented sausage. Meat Sci 82:179-184, 2009.

Kusano T, Berberich T, Tateda C, Takahashi Y: Polyamines: essential factors for growth and survival. Planta 228:367-381, 2008.

Lagishetty CV, Naik SR: Polyamines: Potential anti-inflammatory agents and their possible mechanism of action. Indian $\mathrm{J}$ Pharmac 40:121-125, 2008.

Larqué E, Sabater-Molina M, Zamora S: Biological significance of dietary polyamines. Nutrition 23:87-95, 2007.

Lavizzari T, Veciana-Nogués MT, Weingart O, Bover-Cid S, Mariné-Font A, Vidal-Carou MC: Occurrence of biogenic amines and polyamines in spinach and changes during storage and refrigeration. J Agric Food Chem 55:9514-9519, 2007.

Linsalata M, Russo F: Nutritional factors and polyamine metabolism in colorectal cancer. Nutrition 24:382-389, 2008.

Lorenzo JM, Martínez S, Franco I, Carballo J: Biogenic amine content during the manufacture of dry-cured lacón, a Spanish traditional meat product: Effect of some additives. Meat Sci 77:287-293, 2007.

Lorenzo JM, Martínez S, Franco I, Carballo J: Biogenic amine content in relation to physicochemical parameters and microbial counts in two kinds of Spanish traditional sausages. Arch Lebensmittelhyg 59:70-75, 2008.

Martínez-Villaluenga C, Frías J, Gulewicz $\mathrm{P}$, Gulewicz K, Vidal-Valverde C: Food safety evaluation of broccoli and radish sprouts. Food Chem Toxicol 46:1635-1644, 2008.

Matsumoto M, Benno Y: The relationship between microbiota and polyamine concentration in the human intestine: A pilot study. Microbiol Immunol 51:25-35, 2007.

Matsumoto M, Kakizoe K, Benno Y: Comparison of fecal microbiota and polyamine concentrations in adult patients with intractable atopic dermatitis and healthy adults. Microbiol Immunol 51:37-46, 2007.

Michaelidou AM: Factors influencing nutritional and health profile of milk and milk products. Small Rumin Res 79:42-50, 2008.

Moinard C, Cynober L, de Bandt JL: Polyamines: metabolism and implications in human diseases. Clin Nutr 24184-197, 2005.

Moreira APS, Giombelli A, Labanca RA, Nelson DL, Glória MBA: Effect of aging on bioactive amines, microbial flora, physico-chemical characteristics, and tenderness of broiler breast meat. Poultry Sci 87:1868-1873, 2008.

Moret S, Smela D, Populin T, Conte LS: A survey of free biogenic amine content of fresh and preserved vegetables. Food Chem 89:355-361, 2005.

Nishibori N, Fujihara S, Akatuki T: Amounts of polyamines in foods in Japan and intake by Japanese. Food Chem 100:491-497, 2007.

Nishimura K, Shiina R, Kashiwagi K, Igarashi K: Decrease in polyamines with aging and their ingestion from food and drink. $\mathrm{J}$ Biochem 139:81-90, 2006.

Paulsen P, Bauer F: Spermine and spermidine concentrations in pork loin as affected by storage, curing and thermal processing. Eur Food Res Technol 225:921-924, 2007.

Paulsen P, Hagen U, Bauer F: Changes in biogenic amine contents, non-protein nitrogen and crude protein during curing and thermal processing of M. longissimus, pars lumborum of pork. Eur Food Res Technol 223:603-608, 2006.

Paulsen P, Dicakova Z, Bauer F: Biogenic amines and polyamines in liver, kidney and spleen of roe deer and European brown hare. Eur Food Res Technol 227:209-213, 2008. 
Ralph A, Englyst K, Bardócz S: Polyamine content of the human diet. In Bardócz S, White A (eds.): Polyamines in Health and Nutrition, Kluwer Acad. Publ., London 1999, pp. 123-137.

Rider JE, Hacker A, Mackintosh CA, Pegg AE, Woster PM, Casero RA Jr: Spermine and spermidine mediate protection against oxidative damage caused by hydrogen peroxide. Amino Acids 33:231-240, 2007.

Righetti L, Tassoni A, Bagni N: Polyamines content in plant derived food: A comparison between soybean and Jerusaleme artichoke. Food Chem 111:852-856, 2008.

Ruiz-Capillas C, Jiménez Colmenero F, Carrascosa $\mathrm{AV}$, Muñoz R: Biogenic amine production in Spanish dry-cured "chorizo" sausage treated with high-pressure and kept in chilled storage. Meat Sci 77:365-371, 2007.

Seiler N: Catabolism of polyamines. Amino Acids 26:217-233, 2004.

Til HP, Falke HE, Prinsen MK, Willems MI: Acute and subacute toxicity of tyramine, spermidine, spermine, putrescine and cadaverine in rats. Food Chem Toxicol 35:337-348, 1997.

Toninello A, Pietrangeli P, de Marchi U, Salvi M, Mondovi B: Amine oxidases in apoptosis and cancer. Biochim Biophys Acta 1765:1-13, 2006.
Vieira SM, Theodoro KH, Glória MBA: Profile and level of bioactive amines in orange juice and orange soft drink. Food Chem 100:895-903, 2007.

Wang YL, Casero RA: Mammalian polyamine catabolism: A therapeutic target, a pathological problem, or both? J Biochem 139:17-25, 2006.

Weiger TM, Aichberger S, Wallace HM: A comparison of dietary polyamine uptake by humans in Europe, Asia and the USA. In Proc. COST 922 Workshop Health Implications of Dietary Amines, Coimbra, Portugal 2005, p. 33.

Weiss TS, Herfarth H, Obermeier F, Ouart J, Vogl D, Schölmerich J, Jauch KW, Rogler G.: Intracellular polyamine levels of intestinal epithelial cells in inflammatory bowel disease. Inflamm Bowel Dis 10:529-535, 2004.

Wood PL, Khan MA, Moskal JR: The concept of "aldehyde load" in neurodegenerative mechanisms: Cytotoxicity of the polyamine degradation products hydrogen peroxide, acrolein, 3-aminopropanal, 3-acetamidopropanal and 4-aminobutanal in a retinal ganglion cell line. Brain Res 1145:150-156, 2007.

Zoumas-Morse C, Rock CL, Quintana EL, Neuhouser ML, Gerner EW, Meyskens FL: Development of a polyamine database for assessing dietary intake. J Am Diet Assoc 107:1024-1027, 2007. 